\title{
From Entrepreneurship to Sustainable Entrepreneurship: Why must we care? What must we do?
}

\author{
Ratna Lindawati Lubis \\ Faculty of Economics and Business, Telkom University, INDONESIA \\ Hendra Prasetyanwar \\ Faculty of Economics and Business, Telkom University, INDONESIA
}

\begin{abstract}
The 2030 Agenda for Sustainable Development recognizes that road safety is a prerequisite to ensuring healthy lives, promoting well-being and making cities inclusive, safe, resilient and sustainable. The Sustainable Development Goals 2030 or SDGs 2030 are a roadmap for humanity. They encompass almost every aspect of human and planetary wellbeing and, if met, will provide a stable and prosperous life for every person and ensure the health of the planet. Unfortunately, for the first time in a hundred years, the world is focused on a common goal: beating coronavirus. Like a double helix, the SDGs and the COVID-19 pandemic response are intertwined and cannot be tackled by a piecemeal approach. The pandemic permitted us permission to do what was once almost unimaginable-redesign the way we work. COVID-19 is forcing us to revisit our values and design a new era of development that truly balances economic, social and environmental progress as envisioned by the 2030 Agenda and the SDGs. Recognizing this situation, this study aims to inspire universities in Indonesia to take action and support them through their research, learning and teaching, and community development or as known as "Tri Darma Perguruan Tinggi". It does this by offering practical approaches and guidance to both scale up existing activities, as well as implement and mainstream new types of transformative learning activities, which employ interdisciplinary, action-based learning, and multi-actor involvement, and which go beyond usual operations.
\end{abstract}

Keywords: “Tri Darma Perguruan Tinggi”; transformative learning; SDGs 2030; COVID-19; Indonesia 